\title{
Conventions and Abbreviations
}

DTKYL Da Tang Kaiyuan li 大唐開元禮. Ed. Xiao Song 蕭嵩 (?-749). In Qingding siku quanshu 欽定四庫全書考證. Taibei: I wen, 1969. Citations given by fascicle and page of the Da Tang Kaiyuan li.

DZ Daozang 道藏. Numbers provided for texts found in the Daoist canon follow the ordering of the Ming Dynasty canon according to Kristofer Marinus Schipper, and Franciscus Verellen, eds., The Taoist Canon: A Historical Companion to the Daozang, 3 vols. (Chicago: University of Chicago Press, 2004).

Daoist sources are drawn from the Zhonghua daozang published in 2004 by Huaxia Publishing. Citations are given as Daozang scripture number, Zhonghua edition volume number, page, register, and line number.

JSL Da Tang jiaosi lu 大唐郊祀錄. Taibei: I wen, 1967. Citations given by fascicle and page.

JTS Jiu Tangshu 舊唐書 (Older Tang History). Ed. Liu Xu (887-946). Beijing: Zhonghua shuju chuban faxing, 1975. Reprint, 2002. Citations given by fascicle and page.

T Taishō Shinshū Daizōkyō 大正新脩大藏經. Ed. Takakusu Junjiro 高楠順次郎. Tokyo: Taisho Shinshu Daizokyo Kankokai, 1960. Citations given by text number, page, register, and line.

TBYJ Taibai yinjing 太白陰經. Li Quan 李鉒. Shen Ji Zhi Di Tai Bai Yin Jing 神機製敵太 白陰經. In Baibu congshu jicheng 百部叢書集成 6, case no. 8. Taibei: Yi wen, 1968. Passages from the Taibai yin jing are cited by fascicle, section number, and page. 


\section{CONVENTIONS AND ABBREVIATIONS}

TPGJ Taiping guangji 太平廣記. Ed. Li Fang 李昉. Beijing: Zhonghua shujuchuban faxing, 2003. Citations given by fascicle and page.

QTW Quan Tang wen 全唐文. Dong Hao. Quan Tang wen. Beijing: Zhonghua shu ju, 1983. Citations given by fascicle and page

XTS Xin Tangshu 新唐書. Ed. Ouyang Xiu 歐陽修. Beijing: Zhonghua shujuchuban faxing, 1975. Reprint, 2002. Citations given by fascicle and page.

ZZTJ Zizhi tongjian 資治通鑑. Ed. Sima Guang 司馬光. Beijing: Guji chubanshe, 1956. Citations from the Zizhi tongjian are given by fascicle number, reign title and year, and section number as provided in this edition. 
Chinese Esoteric Buddhism 
